\title{
Kualitas Udara Selama Perjalanan di Kapal Motor Camara Nusantara 3
}

\author{
Air Quality During Journey Inter-island On Camara Nusantara 3 Ship
}

\author{
D. Talithania ${ }^{*}$, Salundik ${ }^{2}$, \& A. Yani ${ }^{2}$ \\ ${ }^{1}$ PostGraduate of Animal Production and Technology, Faculty of Animal Science, IPB University \\ ${ }^{2}$ Department of Animal Production and Technology, Faculty of Animal Science, IPB University \\ Agatis St, Campus IPB Darmaga Bogor 16680, Indonesia \\ *Email koresponden author: talithania_1910@apps.ipb.ac.id \\ (Received 20-01-2020; Revised 16-03-2020; Accepted 26-04-2020)
}

\begin{abstract}
The Camara Nusantara Ship is a mode of transportation used for transporting cattle to various islands. The journey from Kupang, East Nusa Tenggara to Jakarta took five days. The gases that produced during the trip on the ship were ammonia, methane, carbon dioxide, and carbon monoxide. This aim of research to analysis the air quality of each deck on the ship during transportation and inform the threshold of gas concentration as well as strategies to improve air quality for livestock on the Camara Nusantara Ship. Measurements were taken three times: morning (8 am), noon (12 pm) and afternoon (4 pm). Observation of the gas concentration level was carried out for 10 - 15 minutes. The study was conducted observation, and data analysis was done descriptively. The results showed that the level of gas concentration still in the normal range and below the threshold value and the microclimate on the deck still in the normal range. Another factor that influence air quality were still in the safe category, namely wind speed. Strategies that can be applied to anticipate the decline in air quality by improving the ventilation system on the ship by focusing more on the engine airflow on the vessel.
\end{abstract}

Keywords: air quality, bali cattle, gases, Camara Nusantara Ship

\section{ABSTRAK}

Kapal Camara Nusantara adalah moda transportasi yang digunakan untuk mengangkut ternak ke berbagai pulau. Perjalanan dari Kupang, Nusa Tenggara Timur ke Jakarta memakan waktu lima hari. Gas-gas yang dihasilkan selama perjalanan di kapal antara lain amonia, metana, karbon dioksida, dan karbon monoksida. Penelitian ini bertujuan untuk menganalisis kualitas udara setiap geladak di kapal selama pengangkutan dan menginformasikan ambang batas konsentrasi gas serta strategi untuk meningkatkan kualitas udara untuk ternak di Kapal Camara Nusantara. Pengukuran dilakukan tiga kali: pagi (8 pagi), siang (12 siang) dan sore (4 sore). Pengamatan tingkat konsentrasi gas dilakukan selama 10 - 15 menit. Penelitian dilakukan observasi, dan analisis data dilakukan secara deskriptif. Hasil penelitian menunjukkan bahwa tingkat konsentrasi gas masih dalam kisaran normal dan di bawah nilai ambang batas serta iklim mikro di geladak masih dalam kisaran normal. Faktor lain yang mempengaruhi kualitas udara masih dalam kategori aman, yaitu kecepatan angin. Strategi yang dapat diterapkan untuk mengantisipasi penurunan kualitas udara dengan meningkatkan sistem ventilasi di kapal dengan berfokus pada aliran udara mesin pada kapal.

Kata kunci: kualitas udara, sapi Bali, gas, Kapal Camara Nusantara

\section{PENDAHULUAN}

Transportasi di Indonesia telah membuat catatan baru mengenai moda transportasi berbasis laut untuk ternak. Permintaan konsumen dari berbagai daerah, terutama daerah antar pulau menjadi faktor dalam implementasi tol laut. Transportasi ternak telah tertulis dalam Peraturan Menteri
No 28 tahun 2018 mengenai subsidi transportasi laut. Akomodasi melalui laut memiliki beberapa keunggulan yaitu peternak dapat menjual ternaknya ke daerah antar pulau, permintaan dari konsumen terpenuhi, efisiensi waktu pengiriman, biaya akomodasi cukup terjangkau, dan fasilitas di kapal selama perjalanan cukup memadai. Pengoperasian Camara Nusantara Ship 3 dimulai dari Pelabuhan Tenau, 
Kupang menuju Pelabuhan Tanjung Priok, Jakarta selama lima hari. Beberapa tahapan diterapkan untuk menjaga kualitas dan kesejahteraan ternak. Kendala lingkup kapal menjadi keterbatasan yang perlu diperhatikan, terutama dapat mengganggu kenyamanan dan keamanan ternak saat perjalanan. Sementara itu, ternak tidak hanya menghasilkan daging, tetapi menghasilkan produk sampingannya yaitu feses dan urin. Feses dan urin yang diproduksi oleh sapi per hari berkisar 10-25 kg / ekor (Latief et al. 2014).

Produksi sampingan yang dihasilkan oleh sebanyak itu tidak dapat diproses lebih lanjut selama perjalanan. Dampak limbah menumpuk dan menghasilkan bau dapat mencemari lingkungan sekitar. Sisa pakan dapat digunakan sebagai alas lantai dasar untuk mengurangi licin di kandang. Namun, feses dan urin yang dihasilkan oleh ternak tentu memiliki beberapa efek buruk, terutama untuk sanitasi. Keadaan tersebut dapat mencemari lingkungan di sekitar kandang hingga seluruh bagian kapal lainnya. Efek paling tampak dari kondisi seperti ini adalah kualitas udara sekitar lingkungan kapal karena adanya polusi udara.

Kualitas udara adalah tingkat polusi udara bersih (Zhang 2005). Udara segar adalah udara yang bebas dari kotoran. Kualitas udara dapat ditentukan dengan mengukur konsentrasi gas. Menurut Auvermann (2006), definisi polutan udara sebagai senyawa atau bahan ketika digantung atau dicampur dengan udara menyebabkan penurunan kualitas dan merusak utilitas untuk berbagai keperluan terutama polusi gas yang dihasilkan memiliki sifat korosif. Polusi udara yang dihasilkan oleh feses dan urin adalah gas amonia $\left(\mathrm{NH}_{3}\right.$ dan gas metana $\left(\mathrm{CH}_{4}\right)$. Gas itu adalah yang paling umum terdeteksi ketika dikaitkan dengan produk samping ternak. Selain itu, gas-gas lain seperti oksigen $\left(\mathrm{O}_{2}\right)$, karbon dioksida $\left(\mathrm{CO}_{2}\right)$, karbon monoksida $(\mathrm{CO})$ juga terkait dengan kualitas udara.

Faktor lain yang mendukung tingkat polusi udara, yaitu kecepatan kapal, kecepatan udara, sistem ventilasi, jumlah ternak dalam transportasi dan lamanya perjalanan. Polusi udara memiliki nilai ambang batas (NAB). Nilai ambang adalah standar faktor bahaya di tempat kerja sebagai pedoman untuk kontrol sehingga pekerja atau makhluk hidup di sekitar mereka masih dapat mengatasinya tanpa menyebabkan penyakit atau masalah kesehatan dalam pekerjaan sehari-hari mereka untuk tidak lebih dari 8 jam sehari atau 40 jam. minggu menurut SNI 19-0232 (2005).

Berdasarkan tingkat konsentrasi masing-masing gas, faktor yang mempengaruhi, dan sifat gas dapat menghasilkan informasi tentang ambang batas konsentrasi gas untuk ternak selama perjalanan. Penelitian ini bertujuan untuk menganalisis kualitas udara dari setiap dek kapal selama proses transportasi dan menginformasikan ambang batas masing-masing gas serta strategi untuk meningkatkan kualitas udara untuk ternak di Kapal Camara Nusantara.

\section{METODE}

\section{Waktu dan Lokasi Penelitian}

Penelitian dilakukan pada November-Desember 2018. Perjalanan dimulai dari Pelabuhan Tenau, Kupang,
Nusa Tenggara Timur ke Pelabuhan Tanjung Priok, Jakarta selama lima hari.

\section{Alat dan Bahan}

Bahan yang dibutuhkan dalam penelitian ini adalah sapi Bali dari Kupang ke Jakarta. Peralatan yang digunakan untuk mengukur suhu dan kelembaban adalah data logger tipe G-Force Datalogger, dan untuk mengukur kecepatan angin adalah anemometer dengan jenis Benetech GM18 Anemometer. Peralatan yang digunakan untuk analisis kadar konsentrasi gas NH3 adalah Smart Sensor Ammonia Gas Detector AR8500. Alat yang digunakan untuk menganalisis tingkat konsentrasi gas CH4 menggunakan Methana Detector dan untuk menganalisis tingkat konsentrasi gas, yaitu O2, CO dan CO2 menggunakan Air Meter Model $A Q-9901 S D$. Kemudian, pita pengukur dibutuhkan untuk mengukur ukuran pena di kapal.

\section{Prosedur Penelitian}

Ada beberapa langkah sebelum dan selama merekam data. Pengukuran dilakukan tiga kali: pagi (8 pagi), siang (12 siang) dan sore (4 sore) dan pengukuran dilakukan di bagian belakang kapal. Pengamatan tingkat konsentrasi gas dilakukan selama 10 - 15 menit.

Suhu dan kelembaban relatif. Pengukuran suhu dan kelembaban relatif di dek menggunakan data logger. Pengukuran memulai perjalanan dan berakhir di tujuan.

Tingkat konsentrasi gas. Pengukuran tingkat konsentrasi gas cukup dilakukan di lokasi yang telah ditentukan. Pengamatan cukup diambil pada tiga sesi, yaitu: pagi, siang, dan malam. Sebelum waktu pengukuran, setiap jenis peralatan harus melakukan beberapa pengaturan, yaitu tanggal, hari, dan tahun selama pencatatan dan kalibrasi.

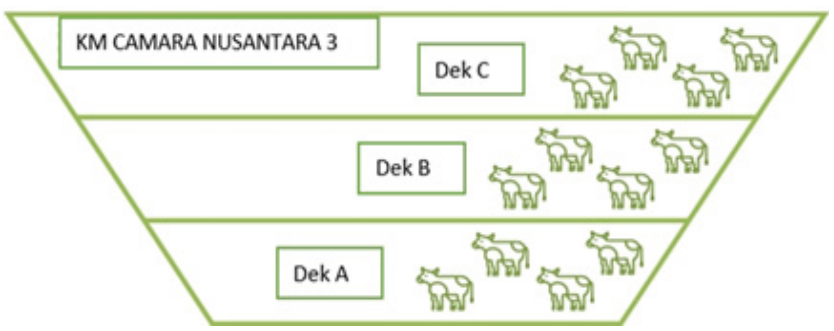

Gambar 1. Lokasi pengukuran selama di kapal perjalanan

\section{Perhitungan}

Perhitungan menggunakan rumus matematika, beberapa data dihitung menggunakan rumus, yaitu:

Kecepatan angin dan kecepatan kapal. Perhitungan menggunakan rumus konversi dari knot ke ms-1.

$$
1 \mathrm{knot}=0,514 \mathrm{~ms}^{-1}
$$

Temperature humidity index (THI). Perhitungan menggunakan rumus menurut Bullita et al. (2015).

$$
\mathrm{THI}=0,8 \mathrm{Tab}+\mathrm{RH}(\mathrm{Tab}-14,4)+46,4
$$

Keterangan:

Tab: Ambient temperature (C)

RH: Humidity (\%) 
Analisis data. Penelitian dilakukan secara observatif. Data yang diperoleh dianalisis secara deskriptif dengan menghitung mean dan standar deviasi. Variabel yang diamati dalam penelitian ini adalah tingkat konsentrasi gas, pengukuran suhu, kelembaban relatif, kecepatan kapal, dan kecepatan angin.

\section{HASIL DAN PEMBAHASAN}

\section{Kondisi Mikroklimat Kandang}

Lingkungan merupakan faktor ekternal non-genetik yang mengaruhi respon dan pertumbuhan ternak (Esmay 1978). Parameter utama yang diamati adalah lingkungan kandang dikapal selama perjalanan. Lingkungan yang diamati terdiri atas suhu lingkungan di kapal dan kecepatan angin. Pengambilan data penelitian dilakukan sebanyak 3 kali sehari, yaitu pagi, siang, dan sore hari. Data penelitian disajikan dalam Tabel 1.

Tabel 1. Mikroklimat dalam kandang di kapal

\begin{tabular}{lccc}
\hline Geladak & Waktu* & \multicolumn{2}{c}{ Parameter } \\
\cline { 2 - 4 } & & $\begin{array}{c}\text { Suhu Kandang } \\
\left({ }^{\circ} \mathrm{C}\right)\end{array}$ & $\begin{array}{c}\text { Kelembaban Relatif } \\
(\%)\end{array}$ \\
\hline A & 8 & $30.6 \pm 0.69$ & $73.1 \pm 2.22$ \\
& 12 & $31.5 \pm 0.45$ & $69.9 \pm 6.32$ \\
& 4 & $31.5 \pm 0.95$ & $69.0 \pm 6.39$ \\
B & 8 & $30.4 \pm 0.52$ & $75.2 \pm 3.26$ \\
& 12 & $30.8 \pm 0.60$ & $72.9 \pm 5.64$ \\
& 4 & $30.5 \pm 1.01$ & $73.5 \pm 6.67$ \\
C & 8 & $31.9 \pm 1.27$ & $69.1 \pm 4.64$ \\
& 12 & $31.5 \pm 1.03$ & $69.4 \pm 5.75$ \\
& 4 & $30.2 \pm 0.54$ & $74.6 \pm 5.72$ \\
\hline
\end{tabular}

Keterangan: waktu $=8$ (pagi), 12 (siang), and 4 (sore)

Suhu adalah indikator tingkat panas oleh ternak ketika di kandang. Hasil pengamatan kisaran suhu kandang antara 30.2-31.9 ${ }^{\circ} \mathrm{C}$. Suhu lingkungan selama perjalanan ini berada dalam kisaran optimal untuk ternak di daerah tropis menurut Das et al. (2013) adalah 25-37 ${ }^{\circ} \mathrm{C}$. Suhu kandang tertinggi ditemukan di geladak A dan geladak C. Peningkatan suhu sekitar geladak A dan C disebabkan oleh posisi geladak. Dek A adalah dek bawah dan dek C adalah dek atas. Efek lain dari penyebabnya adalah 1), posisi dek A di bagian bawah dan di samping ruang mesin kapal. Upaya untuk menangani suhu panas dan kelembaban relatif digunakan mesin ventilator. 2) Posisi dek C di bagian atas dan mendapat paparan langsung oleh panas matahari dikarenakan pada bagian atap dek tidak terdapat naungan apapun sehingga panas menyerap langsung kedalam kandang.

Suhu kandang yang semakin meningkat dapat membuat ternak mengalami stres karena stres panas. Tekanan panas pada ternak akan mengurangi kinerja dan profil kesehatan ternak dan suhu lingkungan yang tinggi akan memicu produksi gas selama perjalanan di kapal. Selain suhu, kelembaban relatif merupakan faktor penting yang perlu dipertimbangkan untuk transportasi pada ternak. Hubungan antara suhu dan kelembaban disajikan pada Tabel 1.

Kelembaban udara kandang di kapal berkisar 69\%$74.6 \%$ dan masih dikategorikan normal. Sesuai dengan pernyataan dari Meyer et al. (1991) bahwa kelembaban udara kandang yang optimal untuk sapi sebesar 70\%$76.5 \%$. Tinggi rendahnya suhu lingkungan berhubungan dengan tingkat kelembaban udara. Peningkatan kelembaban udara pada geladak berdampak pada produksi gas amonia di kandang. Menurut Nuriyasa (1991) bahwa besaran kelembaban udara relatif yang terukur di dalam kandang tegantung pada sumber uap air, kecepatan angin dan suhu udara sebagai pengendali laju evaporasi.

Temperature humidity index atau THI merupakan interaksi antara suhu dan kelembaban yang mengindikasikan tingkat kenyamanan ternak. Pengaruh lokasi geladak terhadap THI disajikan dalam Tabel 2. Nilai THI yang didapatkan yakni 78.3-80.8. Nilai tersebut termasuk dalam kategori stress sedang menurut Bullita et al. (2015) yang memiliki beberapa kategori stress terhadap nilai THI, yaitu kategori normal $(\leq 74)$, kategori stress ringan $(75$ 78), kategori stress sedang (79-83), dan kategori stress berat $(\geq 84)$. Suhu kandang berbanding lurus terhadap nilai THI yang tinggi. Berdasarkan pengelompokkan nilai THI tersebut, ternak selama perjalanan mengalami stress sedang. Hal ini berkaitan dengan semakin tinggi nilai THI dari kisaran optimum, semakin tinggi tingkat cekaman panas yang dialami oleh ternak. Selain itu, dampak yang terlihat dari tingginya nilai THI terlihat dari perilaku sapi selama perjalanan.

Tabel 2. Nilai THI dan kecepatan angin dalam kandang di kapal

\begin{tabular}{lccc}
\hline Geladak & Waktu* & \multicolumn{2}{c}{ Parameter } \\
\cline { 2 - 4 } & & THI & $\begin{array}{c}\text { Kecepatan Angin } \\
(\mathrm{m} / \mathrm{s})\end{array}$ \\
\hline A & 8 & $78.8 \pm 1.06$ & $0.3 \pm 0.4$ \\
& 12 & $80.3 \pm 0.68$ & $0.6 \pm 0.5$ \\
& 4 & $80.2 \pm 1.46$ & $0.1 \pm 0.1$ \\
$\mathrm{~B}$ & 8 & $78.5 \pm 0.79$ & $0.6 \pm 0.2$ \\
& 12 & $79.2 \pm 0.92$ & $1.0 \pm 0.2$ \\
& 4 & $78.6 \pm 1.55$ & $0.9 \pm 0.5$ \\
$\mathrm{C}$ & 8 & $80.8 \pm 1.95$ & $0.3 \pm 0.4$ \\
& 12 & $80.3 \pm 1.58$ & $0.1 \pm 0.1$ \\
& 4 & $78.3 \pm 0.83$ & $0.2 \pm 0.2$ \\
\hline
\end{tabular}

Keterangan: waktu $=8$ (pagi), 12 (siang), and 4 (sore)

Angin berfungsi sebagai distributor panas ke daerah dingin. Angin sebagai kapal pemasok gas utama, yang merupakan gas oksigen. Udara yang memasuki kapal mempengaruhi suhu, kelembaban, dan tingkat persentase gas $\mathrm{CO}_{2}$ (Utomo 2007). Hasil penelitian menunjukkan data kecepatan angin berkisar antara $0.2 \mathrm{~ms}^{-1}-0.9 \mathrm{~ms}^{-1}$. Kecepatan angin per dek setidaknya $0.5 \mathrm{~ms}^{-1}$ menurut Australian Maritime Safety Autority (2006). Nilai kecepatan angin berbanding lurus dengan suhu dan kelembaban data. Nilai 
kecepatan angin diperoleh dari proses pertukaran udara di sistem ventilasi kapal. Pada dek B dan dek C, angin masuk melalui sistem ventilasi alami dengan membentuk lubang di aliran udara atau angin untuk masuk dan keluar secara alami sebagai akibat dari perbedaan tekanan di luar dengan di dalam kapal. Pada dek $\mathrm{C}$ kecepatan angin tidak lebih tinggi dari dek B karena posisi dek di atas. Sesuai dengan prinsip, semakin tinggi posisi ruangan, semakin kecil tekanan dan semakin rendah aliran angin yang masuk. Sementara itu, tekanan di permukaan laut lebih besar daripada tekanan di atas. Alasan kecepatan angin di geladak B lebih besar karena posisi geladak tidak jauh dari permukaan laut dan angin yang masuk lebih karena ada jalur loading-unloading.

Selain itu, faktor lain dari kecepatan angin di kandang adalah kecepatan kapal dan luasan ventilasi. Kecepatan kapal selama perjalanan sebesar $4.56 \mathrm{~ms}^{-1}-4.72$ $\mathrm{ms}^{-1}$. Semakin tinggi kecepatan kapalnya, maka semakin besar kecepatan angin yang dirasakan seiring dengan luasan ventilasi pada kapal. Ukuran ventilasi pada dek A berdiameter $70 \mathrm{~cm}$, sedangkan untu dek B dan dek C luasan ventilasi sebesar $1.8 \mathrm{~m}$ dengan masing-masing ketinggian tiap dek sebesar $2.3 \mathrm{~m}$. Menurut Meat and Livestoock Australia (2001) dan Australian Maritime Safety Authority (2006) menyatakan bahwa pada ketinggian dek sebesar $2.3 \mathrm{~m}$ dan kecepatan angin sekurang-kurangnya $0.5 \mathrm{~m}$, pertukaran udara yang terjadi sebanyak 20 kali pertukaran per jamnya. Kecepatan udara yang meningkat dapat menurunkan suhu kulit yang dibutuhkan untuk menurunkan panas metabolik tubuh. Selain itu, pertukaran udara yang terjadi di kapal dapat menurunkan produksi gas $\mathrm{NH}_{3}$ dan $\mathrm{CO}_{2}$ (Meat and Livestock Australia 2001).

\section{Produksi Gas-Gas Selama Perjalanan}

Selama perjalanan berlangsung, gas-gas berproduksi dari ternak maupun dari lingkungan luar kapal. Beberapa faktor pendukung seperti banyak ternak, sistem ventilasi dilihat keterikatannya dengan produksi dan distribusi gas di kapal. Tingkat konsentrasi gas di kapal disajikan dalam Tabel 3 dan 4.

Gas oksigen di kapal sebagai indikator ketersediaan udara bersih untuk ternak bernapas. Hasil penelitian menunjukkan gas oksigen antar dek tidak berbeda satu

Tabel 3. Konsentrasi gas oksigen $\left(\mathrm{O}_{2}\right)$, karbon dioksida $\left(\mathrm{CO}_{2}\right)$, dan karbon monoksida (CO) selama perjalanan di kapal

\begin{tabular}{lcccc}
\hline Geladak & Waktu* & \multicolumn{3}{c}{ Parameter } \\
\cline { 2 - 5 } & & $\mathrm{O}_{2}(\mathrm{ppm})$ & $\mathrm{CO}_{2}(\mathrm{ppm})$ & $\mathrm{CO}(\mathrm{ppm})$ \\
\hline $\mathrm{A}$ & 8 & $20.6 \pm 0.12$ & $468.0 \pm 41.75$ & $2.0 \pm 0.76$ \\
& 12 & $20.6 \pm 0.25$ & $535.6 \pm 44.22$ & $1.2 \pm 0.87$ \\
& 4 & $20.5 \pm 0.26$ & $488.5 \pm 32.54$ & $1.1 \pm 0.72$ \\
$\mathrm{~B}$ & 8 & $20.6 \pm 0.10$ & $463.3 \pm 33.76$ & $1.0 \pm 0.45$ \\
& 12 & $20.5 \pm 0.12$ & $535.6 \pm 58.35$ & $0.9 \pm 0.82$ \\
& 4 & $20.5 \pm 0.19$ & $452.3 \pm 36.32$ & $1.7 \pm 0.25$ \\
$\mathrm{C}$ & 8 & $20.7 \pm 0.20$ & $459.9 \pm 33.64$ & $1.7 \pm 0.25$ \\
& 12 & $20.5 \pm 0.18$ & $497.9 \pm 61.18$ & $1.3 \pm 0.56$ \\
& 4 & $20.5 \pm 0.13$ & $469.3 \pm 48.93$ & $1.2 \pm 0.44$ \\
\hline
\end{tabular}

Keterangan: waktu $=8$ (pagi), 12 (siang), and 4 (sore) sama lain. Tingkat konsentrasi gas $\mathrm{O}_{2}$ selama perjalanan ditampilkan pada Tabel 3. Nilai konsentrasi gas oksigen dikapal melebihi standar yang ditetapkan, yaitu 19.5\% (Marine Industrial Safety Section 2013). Hasil menunjukan bahwa kualitas udara berupa oksigen tidak terganggu dengan adanya pengangkutan ternak pada tiap dek. Selain itu, adanya limbah ternak tidak mempengaruhi kadar oksigen udara secara signifikan. Faktor dari keberadaan gas oksigen adalah sistem ventilasi, kepadatan ternak di pen, kecepatan angin, dan kecepatan kapal.

Tabel 4. Konsentrasi gas metan $\left(\mathrm{CH}_{4}\right)$ dan amonia $\left(\mathrm{NH}_{3}\right)$ selama perjalanan di kapal

\begin{tabular}{lccc}
\hline Geladak & Waktu* & \multicolumn{2}{c}{ Parameter } \\
\cline { 2 - 4 } & & $\mathrm{CH}_{4}(\mathrm{ppm})$ & $\mathrm{NH}_{3}(\mathrm{ppm})$ \\
\hline $\mathrm{A}$ & 8 & $4.1 \pm 3.61$ & $2.5 \pm 0.56$ \\
& 12 & $6.0 \pm 2.78$ & $3.3 \pm 0.72$ \\
& 4 & $4.6 \pm 3.54$ & $3.0 \pm 0.59$ \\
$\mathrm{~B}$ & 8 & $2.3 \pm 3.13$ & $3.0 \pm 0.61$ \\
& 12 & $4.2 \pm 2.83$ & $3.3 \pm 2.80$ \\
$\mathrm{C}$ & 4 & $0.7 \pm 0.50$ & $2.8 \pm 0.42$ \\
& 8 & $3.1 \pm 3.23$ & $3.4 \pm 0.99$ \\
& 12 & $1.1 \pm 0.90$ & $3.9 \pm 1.10$ \\
& 4 & $0.4 \pm 0.65$ & $2.6 \pm 0.36$ \\
\hline
\end{tabular}

Keterangan: waktu $=8$ (pagi), 12 (siang), and 4 (sore)

Gas karbon dioksida adalah gas 'pelacak' yang menggunakan tingkat keamanan atau kontaminan yang efektif (Meat and Livestock Australia 2001). Tingkat konsentrasi gas $\mathrm{CO}_{2}$ dalam penelitian ini adalah 452.3 - 535.6 ppm. Nilai ambang batas gas $\mathrm{CO}_{2}$ sebesar $1,500-2,000$ ppm (Donham et al. 2000). Hasil penelitian menunjukkan bahwa produksi gas masih dalam kisaran normal. Produksi gas $\mathrm{CO} 2$ tertinggi terletak pada geladak A disebabkan sistem ventilasi pada geladak tersebut menggunakan ventilasi mekanik dengan alat bantuan air flow. Meskipun jumlah ternak pada dek A tak lebih banyak dari dek B, distribusi gas dengan sistem ventilasi yang tertutup menimbulkan penumpukkan gas pada dek tersebut sehingga proses pertukaran gas dari dalam kandang menuju keluar tidak terjadi secara maksimal. Selaras dengan pernyataan Barber et al. (1993) bahwa gas $\mathrm{CO}_{2}$ dapat dipantau sebagai indikator efisiensi ventilasi dan hal itu sesuai dengan hasil penelitian ini. Faktor lain yang mempengaruhi produksi gas $\mathrm{CO}_{2}$ di kapal adalah kecepatan angin. Kecepatan angin di setiap dek dapat memengaruhi suhu udara, kelembaban, dan tingkat konsentrasi gas $\mathrm{CO}_{2}$ di dalam kandang. Semakin rendah aliran udara di dek, semakin rendah pertukaran udara yang terjadi dan semakin tidak efisien pertukaran udara yang terjadi.

Gas karbonmonoksida merupakan salah satu emisi gas yang terdeteksi saat mengukur kualitas udara. Data kadar gas CO pada penelitian ini disajikan dalam Tabel 3. Nilai ambang batas dari gas $\mathrm{CO}$ adalah seminimal mungkin. Menurut SNI (2005) nilai ambang batas gas CO sebesar 25 ppm. Berdasarkan standar dari litelatur, produksi gas CO didalam kapal selama perjalan berkisar 0.9 - 2.0 ppm 
masih dikategorikan normal cenderung rendah. Sifat dari gas CO beracun. Mekanisme gas ini bila terhirup ke dalam saluran pernapasan akan terikat oleh darah dan terdistribusi ke seluruh tubuh. Kemudian, tubuh pengidap mengalami keracunan gas dan bisa menyebabkan kematian. Sumber keberadaannnya gas $\mathrm{CO}$ dari hasil pembakaran yang tidak sempurna seperti pada kayu bakar, batu bara, dan minyak tanah (McCarthy dan Banhazi 2016). Kadar CO di kandang dimungkinkan berasal dari mesin penggerak kapal.

Methana adalah gas yang tidak berwarna dan berbau dan berkaitan dengan kontribusi emisi gas rumah kaca. Data tingkat konsentrasi gas methan selama perjalanan ditampilkan pada Tabel 4. Berdasarkan data tersebut, dapat dikatakan konsentrasi gas methan dikapal masih dalam batas wajar bahkan cendrerung rendah.

Tingkat konsentrasi gas methan pada dek A lebih tinggi dibandingkan dengan dek yang lain. Hal ini dikarena pada dek A sistem ventilasi yang sangat minim sehingga pertukaran udara pada dek tersebut dikategorikan tidak maksimal. Pertukaran udara pada dek A dibantu menggunakan blower. Namun, terdapat beberapa blower yang tidak berfungsi sehingga gas methan tidak dapat menguap dan berdistribusi dengan baik. Pada dek C, tingkat konsentrasi gas methannya terendah hal ini dikarenakan dek $\mathrm{C}$ merupakan dek paling atas diantara yang lain dan sistem ventilasinya paling besar sehingga pertukaran udara sangat baik terjadi di kapal. Nilai ambang batas (NAB) gas methan menurut SNI 19-0232 (2005) belum adanya penetapan standarnya, khususnya untuk dikapal. Sedangkan, menurut Alberta Agriculture Food and Rural Development (2004) menyatakan ambang batas dari emisi gas methan sebesar 1,000 ppm selama delapan jam. Gas methan memiliki sifat menguap atau volatile yang berkaitan dengan temprature. Semakin tinggi temperatur lingkungannya, maka semakin tinggi pula proses penguapan gas methan dari limbah ternak di dek kapal. Dalam kapal ternak, gas methana tidak dianggap berkontribusi terhadap masalah kesehatan hewan. Konsentrasi gas yang rendah tidak tergolong berbahaya untuk kesehatan. Produksi gas methan dari feses ternak dipengaruhi oleh faktor lingkungan seperti suhu, komposisi biomassa, dan penanganan feses ternak (Puspitasari 2015).

Amonia bersumber dari hasil kimiawi dan biologis bahan limbah (feses dan urine) (Groot Koerkamp et al. 1998). Data tingkat konsentrasi gas amonia selama perjalananan ditampilkan pada Tabel 4. Berdasarkan penelitian, data amonia yang didapatkan masih dalam kisaran normal. Nilai ambang batas gas amonia menurut Australian Standart and Export of Livestock (2011) adalah 25 ppm. Jumlah banyak ternak tiap deknya antara lain: dek A sebanyak 36 ekor, dek B sebanyak 43 ekor, dan dek C sebanyak 36 ekor. Tingginya kadar amonia pada dek $\mathrm{C}$ dipengaruhi oleh suhu udara pada dek yang tinggi dan kecepatan angin yang lebih rendah dari dek lainnya. Fungsi dari kecepatan angin adalah untuk mengaliri udara didek. Namun, karena ketidakmasimal aliran udara mengakibatkan gas menumpuk pada beberapa bagian kapal dan tidak terjadi petukaran dengan baik. Sisa dari pembusukan pakan dan limbah ternak menjadi salah satu faktor pendukung dari produksi gas amonia. Amonia sendiri dihasilkan dari aktifitas enzim urease yang memecah urea dalam feses dan urine yang konsentrasinya dipengaruhi oleh suhu sekitar, konsentrasi urine dan tingkat $\mathrm{pH}$ pada kandang (Pines dan Phlips 2011).

\section{KESIMPULAN}

Kualitas udara tiap dek masih di bawah nilai ambang batas. Strategi yang dapat diterapkan untuk mengantisipasi penurunan kualitas udara dengan meningkatkan sistem ventilasi pada kapal, khusunya pada distribusi udara pada didalam kandang.

\section{UCAPAN TERIMA KASIH}

Penulis mengucapkan terima kasih kepada ALIN (Animal Logistic Indonesia Netherland) - NICHE (Netherland Initiative for Capacity Development in Higher Education) 2018-2019, Dosen Pembimbing, field coordinator lecturer, Dinas Peternakan Provinsi NTT , PT PELNI, and the Kapten dan kru dari Kapal Camara Nusantara 3, serta teman satu penelitian.

\section{DAFTAR PUSTAKA}

Alberta Agriculture Food and Rural Development. 2004. Metahane $\left(\mathrm{CH}_{4}\right)$ Safety. Alberta, Canada (CA): AgriFacts

Australian Standards for the Export of Livestock. 2011. Australian Standards for the Export of Livestock (version 2.3) 2011 and Australian Position Statement Export of Livestock. Canberra (AU): Australian Goverment Department of Agriculture, Fisheries and Forestry.

Auvermann, B., Bottcher, R., Heber, A., Meyer. D., Parnell, C. B., Shawm B. Jr., \& Worley, J. 2006. Particulate matter emissions from animal feeding operations. In Animal Agriculture and the Environment: National Center for Manure and Animal Waste Management White Papers. J.M. Rice, D.F. Caldwell, F.J. Humenik. Eds. St. Joseph, Mich.: ASABE.

Bullita, F. S., Aradom, S., \& Gebresent, G. 2015. Effect of Trasnport Time of Upon to 12 Hoursd on Welfare of Cows and Bulls. J Serv Sci Manag. 8:161-162.

Das, R., Sailo, L., Verma, N., Bharti, P., Saikia, J., Imtiwati, \& Kumar, R. 2016. Impact of heat stress on health and performance of dairy animals. Vet World. 9(7):260-268

Donham, K. J., Cumro, D., Reynolds, S. J., \& Merchant, J. A. 2000. Dose-response relationships between occupational aerosol exposures and cross-shift declines of lung function in poultry workers: Recommendations for exposure limits. J Occup Environ Med. 42:260-269.

Esmay, M. L. 1978. Principle of Animal Environment. Westport : The Avi Publishing Company Inc.

Groot Koerkamp, P. W. G., Metz, J. H. M., Uenk, G. H., Phillips, V. R., Holden, M. R., Sneath, R. W., Short, J. L., White, R. P., Hartung, J., Seedorf, J., Schroder, M., Linkert, K. H., Pedersen, S., Takai, H., Johnsen, J. O., \& Wathes, C. M. 1998. Concentrations and Emissions of Ammonia in Livestock Buildings in 
Northern Europe. J Agric Eng Res. 70:79-95.

Lakitan, B. 1994. Dasar Dasar Klimatologi. Jakarta (ID) : Raja Grafindo Persada.

Latief, R., Endro, Sutrisno., \& Mochtar, Hadiwidodo. 2014. Pengaruh Jumlah Kotoran Sapi terhadap Konsnetrasi Gas Amonia (NH3) di dalam rumah. Malang (ID): Jurnal Teknik Lingkungan Universitas Diponegoro. 3(1).

Marine Industiral Safety Section. 2013. Code Of Practice Working In Confined Space on Vessels. Hongkong (HK): Marine Department, The Goverments of Hongkong Special Administrative Region of People's Republic of China.

Meat and Livestock. 2001. Investigation of the Ventilation Efficacy on Livestock Vessels. North Sydney (AUS): MIAMIC Pty Ltd.

McCarthy, M. \& Banhazi, T. 2016. Bedding Management and Air Quality on Livestock Vessel- A Litelature Review-. [Final Report]. Sydney (AU): Meat and Livestock Australia Ltd.

Meyer, D. M., M. J. Brouk, \& L. C. Hollis. 2010. Effect of Heat Stress on Dairy Calves. Manhattan (US) : Kansas State University.
Nuriyasa, I. M. 1991. Pengaruh Bahan Atap dan Kepadatan Kandang terhadap Penamilan Ayam Pedaging [Tesis]. Program Pascasarjana Institut Pertanian Bogor. Bogor (ID): IPB Press.

Pines, M. K. \& Philips, C. J. C. 2011. Accumulation of ammonia and other potentially noxious gases on live export shipments from Australia to the Middle East. Australia (AU): University of Queensland, Center for Animal Welfare and Ethics, School of Veterinary Science.

Puspitasari, R. 2015. Evaluasi Gas Rumah Kaca (CH4, CO2, dan N2O) dari Feses( Sapi FH Laktasi yang diberikan Pakan Rumput Gajah dan Jerami Padi [tesis]. Bogor (ID): IPB Pr.

Standar Nasional Indonesia. 2005. SNI-19-0232-2005 Nilai Ambang Batas Zat Kimia di Tempat Kerja. Jakarta (ID): Badan Standarisasi Nasional.

Utomo, Budi. 2007. Sistem Ventilasi dalam Kapal. Semarang (ID): Jurnal Teknik. 28(1), ISSN 0852-1697.

Zhang, Yuanhui. 2005. Indoor Air Quality Engineering. Florida (US): CRC Pr. 